\title{
PROGRAMAS DE SAÚDE: ANÁLISE CRÍTICO-COMPARATIVA DE LIVROS-TEXTO*
}

\author{
Maria Angela Quilici de Medeiros**
}

MEDEIROS, M.A.Q. de Programas de Saúde: análise crítico-comparativa de livros-texto. Rev. Esc. Enf. USP, São Paulo, 23(3):257-293, dez. 1989.

Os livros-texto de Programas de Saúde, em especial os destinados ao ensino de $1^{\circ}$ grau, raramente sâo livros individuais, que contêm apenas o conteúdo destes programas; freqüentemente, vem estes como "apêndice" de um livro de Ciências. Os de $2^{\circ}$ grau constituem um pequeno conjunto de textos, alguns deles passtveis de criticas quanto à didedignidade de conceitos, profundidade de conteúdo e outros requisitos.

Considerando as ponderaçóes acima, a autora julgou necessária a realização deste estudo, pois os livros didaticos de Programas de Saúde ainda permanecem pouco explorados, apesar de existirem inumeros artigos e teses sobre o livro-texto de outras disciplinas.

Os resultados do presente estudo fornece-nos uma caracterização do professor que desenvolve os Programas de Saude, como também uma analise dos livros-texto destinados a estes programas quanto aos elementos mecánicos, organização e apresentação do conteúdo, conteúdo propriamente dito, exercicios, ilustraçōes, referências bibliográficas e Indices, apêndices, prefácio e glossário.

UNITERMOS: Livros texto - Avaliação. Programas de sauide. Educação em saúde.

\section{INTRODUÇĀO}

Em todos os países do mundo são utilizados para o ensino os mais variados tipos de material didático. OLIVEIRA ${ }^{36}$ classifica-os em: instrumental ou de trabalho: ilustrativo ou audiovisual; experimental $e$ informativo. Como material informativo considera-se qualquer tipo de publicação que divulgue idéias ou fatos. Assim, entre eles, é incluído o livro didático: "o mais importante e acessível meio auxiliar de ensino à disposição dos professores no Brasil"1.

As instituições escolares de $1^{\circ}$ e $2^{\circ}$ graus em nosso país vêm utilizando há mais de um século, o livro-texto, como um recurso didático impresso, tendo sido,

\footnotetext{
* Resumo do relatorio final de pesquisa.

* Enfermeira Auxiliar de Ensino do Departamento de Orientaçāo Profissional da Escola de Enfermagem da Universidade de São Paulo - disciplina Didática aplicada à Enfermagem.
} 
inclusive, objeto de estudo comparativo realizado por BARBANTI ${ }^{4}$, estudo este que contribuiu para a história do livro didático brasileiro.

A Reforma de Ensino, instituída pela Lei no 5692/71* revolucionou o sistema educacional brasileiro que passou a dar maior importância ao livro como instrumento de trabalho indispensável.

Uma pesquisa realizada por FRANCO ${ }^{21}$ revelou que $80 \%$ dos professores consultados utilizam os livros didáticos para ministrarem suas aulas. $\mathrm{O}$ tradicional livro didático - considerado um dos mais antigos materiais instrucionais - está presente de maneira significativa em nossas escolas.

"O livro didático é a principal leitura da maioria da população estudantil que freqüenta o primeiro grau e, em conseqüência, o principal canal de comunicação escrita na transmissão de uma concepção de Ciência, cientista e método científico $^{7} "$.

É muito provável que os livros didáticos sejam os únicos livros com os quais interage a grande maioria da população em idade escolar ${ }^{21,32}$.

O Centro Latino-Americano de Pesquisas em Ciências Sociais vem desenvolvendo no Brasil, desde 1972, um trabalho sobre o livro, e já concluiu que, em aproximadamente $70 \%$ das casas de alunos de condição sócio-econômica menos favorecida os livros, quando existem, são livros didáticos.

$\mathrm{Na}$ restropectiva histórica sobre o livro didático no Brasil, OLIVEIRA ${ }^{36}$ afirma que os tradicionais eram centrados nos conteúdos e na apresentação de informações, não se preocupando com as necessidades de aprendizagem do aluno e ignorando o processo ensino/aprendizagem. Posteriormente, o livro começou a ser um elemento integrante do ensino, atentando para os comportamentos desejados (visão behaviorista), os eventos correspondentes a atividades internas manipuláveis externamente (visão neo-behaviorista) e o processamento de informações e desenvolvimento dos processos intelectuais (visão cognitivista). Desde então, na elaboração dos livros didáticos, os autores preocuparam-se com os objetivos do ensino, o nível de desempenho esperado dos alunos, a adequação entre conteúdos e objetivos, práticas de desempenhos finais e outros.

Todo livro, a princípio, pode ser utilizado para fins didáticos, ou seja, numa situação deliberadamente estruturada, com o objetivo de ensinar algo a alguém. Porém, de acordo com MOLINA ${ }^{32}$, não é todo livro utilizado para fins didáticos, que se constitui um livro didático, e sim aquela "obra escrita e organizada, com a finalidade específica de ser utilizada numa situação didática, sendo inconfundível porém mutável".

* Documenta, Brasilia, (129): 400-416, ago. 1971. 
Uma análise global sobre este tema revelaria que falta ainda no Brasil, uma lei que defenda o livro dos obstáculos à sua disseminação. É necessário protegê-lo da infiltração de capital estrangeiro e tudo o que dela decorre, como também haver a conscientização de que o livro é, sob certos aspectos, uma indústria de base inalienável.

Num dos simpósios realizados da XXVIII Reunião Anual da Sociedade Brasileira para o Progresso da Ciência (S.B.P.C.) ${ }^{43}$ em 1977, o tema foi o problema do livro brasileiro, pois a situação era e é muito precária: o mercado interno é estreito, o externo inviável e a penetração do capital estrangeiro no campo editorial avassaladora - atualmente no Brasil, as editoras estrangeiras controlam $70 \%$ do mercado de livros técnicos.

Dentre os vários depoimentos deste evento, encontramos o de DUARTE (apud $^{43}$ ) o qual afirma que as escolas modernas, com o uso de audiovisuais e apostilas, agem desonestamente com os autores que vêem seus textos reproduzidos sem permissão e sem receberem, por isso, os direitos autorais*9 a que fazem juz. Para ele, o livro é insubstituível, sendo a imagem e o som suplementos importantes.

Não é apenas o uso de recursos audiovisuais que dificultam a ampla utilização do livro didático, pois ele próprio tornou-se demasiadamente gráfico, deixou de ser um livro de texto para ser um objeto bonito e colorido. Praticamente desapareceram os livros que tratam de determinados assuntos em profundidade, para surgirem os que reduzem o conhecimento a "picadinhos de conhecimentos", facilmente perecíveis ${ }^{43}$.

Infelizmente, numa sociedade capitalista, o fator preponderante é o lucro. Por isso, as editoras adotam inadvertidamente certas artimanhas, cuja consequêencia é a venda de livros que nem sempre são os mais adequados à realidade da população a que se destina. Estes livros não utilizam os recursos pedagógicos como caminho para o desenvolvimento de habilidades intelectuais mais complexas e assumem uma posição passiva diante da realidade social.

Ocorre ainda no Brasil, o absurdo que constitui a política do livro descartável, ou seja, os livros didáticos são utilizados num único ano letivo, sem que haja o reaproveitamento dos mesmos em anos subseqüentes por outros alunos. A conduta oficial do Ministério da Educação e Cultura (MEC) através do Programa do Livro Didático para o Ensino Fundamental (PLIDEF), parece contribuir para esta situação ${ }^{14}$.

As conseqüências da utilização generalizada de livros descartáveis num país em desenvolvimento e historicamente deficiente em seu sistema educacional, pode agravar a indisponibilidade de livros e materiais didáticos para os alunos mais carentes $^{37}$.

* DOCUMENTO/DIREITOS AUTORAIS 9 
No presente trabalho, o problema do livro descartável não será abordado, o que poderá ser feito em estudo posterior.

O livro didático possui uma dinâmica de consumo diferente dos outros livros: é comprado pelo aluno ou a ele doado, porém escolhido pelo MEC ou pelo professor.

A seleção desses livros não pode limitar-se às suas características extrínsecas e sim, estender-se a uma análise cuidadosa dos quesitos intrínsecos, de modo a auxiliarem no desenvolvimento real dos alunos.

Segundo CYSNEIROS ${ }^{20}$, a análise de um livro-texto deve efetuar-se em três etapas atendendo-se aos aspectos gerais, a apreciação do conteúdo e aos aspectos didáticos.

Como refere MUNIZ ${ }^{34}$, a escolha de livro-texto é uma tarefa trabalhosa e requer um exame cuidadoso do conteúdo, objetivos, acessibilidade, organização, problemas e questōes apresentadas, precisão, utilidade, flexibilidade, interesse e características físicas, tais como tamanho, peso, impressão e ilustrações. Porém, um dos ítens mais importantes é o da exatidão do texto. Muitas vezes há confusão entre conceitos distintos, ou ainda, um novo conceito, por confusão entre conceitos distintos, ou ainda, um novo conceito, por ser posterior à publicação de um livro, pode torná-lo defasado.

A questão dos critérios de seleção e utilização de livros didáticos constitui um sério problema, num país como o Brasil, onde há poucos recursos para a educação e graves problemas tais como os relativos ao ensino de $1^{\circ}$ e $2^{\circ}$ graus. Conforme trabalho publicado por SILVA ${ }^{57}$, há necessidade de se obter, organizar e especificar uma série de informaçōes sobre a criança, o professor e a comunidade, que norteiem a seleção de livros didáticos. O que se verifica é a despreocupação com os padrōes de excelência e adequabilidade dos materiais às clientelas específicas de alunos e professores. A participação do professor deve ir além da mera indicação de um livro dentre muitos desconhecidos que compõem uma lista previamente selecionada: o professor deve ser treinado e instruído para fazer esta indicação.

O importante é estar atento aos abusos por parte de alguns autores e editores que levianamente não priorizam a importância do papel desempenhado pelo livro didático no contexto da educação brasileira atual.

O professor, muitas vezes, escolhe os livros didáticos aleatoriamente, ingenuamente, com uma prévia avaliação descriteriosa. BROOWM \& OLMOSTED (1962) apud PFROMM NETTO et aliii' ${ }^{41}$, fornecem algumas interrogaçöes importantes na seleção de um livro didático:

- "Qual é a reputação ou prestigio do autor?

- Qual a sua formação? 
- Que titulos acadêmicos possui?

- Que experiência tem no assunto de que trata o livro, como professor e como especialista?

- $O$ autor preocupou-se em experimentar o livro antes de sua edição?

- Houve revisöes?

- Que resultados obteve?

- $O$ autor fundamentou-se nos últimos progressos da psicologia e da didática, para preparar a obra?

- O autor é considerado como pessoa imparcial, objetiva, e desapaixonada?

- Escreveu outros trabalhos?

- Que referências existem a respeito?"

A Secretaria da Educação do Estado de São Paulo, pela Resolução no $113 / 70^{53}$ estabeleceu diretrizes para a escolha e adoção de livros didáticos que devem observar: a forma-título, índice, prefácio, glossário, bibliografia, identificação e afeiçoamento físico*, que inclui impressão, encadernação, marginação, ilustraçāo, papel, tamanho dos tipos, espaçamento e linguagem; o conteúdo informativo; a metodologia utilizada; o planejamento pedagógico que possuem; o respeito à filosofia geral da Educação; a existência de manual do professor e os recursos auxiliares de que dispõem. As importantes características acima referidas para seleção e escolha de um livro-texto são abordadas por ALBUQUERQUE ${ }^{1}$, SCHEER et alii ${ }^{54}$ e PHILLIPS \& HARMAN ${ }^{42}$.

Várias foram as tentativas para disciplinar a escolha de livros didáticos, dentre elas tem-se:

a) Parecer no 603/68 do Conselho Federal de Educação (C.F.E.) ${ }^{10}$ que reconhece, em seu artigo 3\%, o problema das mudanças freqüentes e injustificadas dos livros didáticos, como antigo e universal, cabendo aos Estados legislar sobre estes livros.

Baseada neste Parecer, a Coordenadoria do Ensino Básico e Normal do Estado de São Paulo, em 29 de setembro de 1975 baixou portaria (apud MOLINA ${ }^{32}$ ) cujo teor é muito liberal, apelando apenas, para o bom senso do professor e pressupondo que o mesmo tenha conhecimento por ocasião da escolha, de todos os títulos relevantes que o mercado lhe oferece e que conheça os critérios mínimos para avaliação de livros didáticos;

* afeiçoamento: composição grafica e estética do material. 
b) Lei no 1.925/78 do Governo do Estado de São Paulo - Estabelece que os li-

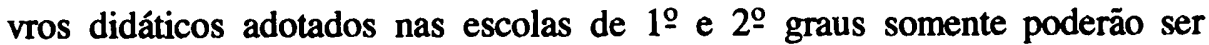
substituídos após quatro anos de adoção $0^{52}$.

Uma das mais importantes características de um livro didático para MOLI$\mathrm{NA}^{32} \mathrm{e}$ a inteligibilidade, que segundo DABE \& CHAKK apud MOLINA ${ }^{32}$ e "a soma total de todos os elementos num material escrito, que afeta o sucesso que um grupo de leitores tenha com ele. $O$ sucesso é a extensão em que a compreendam, leiam numa velocidade ótima e achem-na interessante". No Brasil, desenvolver técnicas apropriadas para se avaliar a inteligibilidade é desenvolver um instrumento interessante para a análise de livros didáticos, tanto por instituiçōes e órgãos governamentais interessados, como por professores que individualmente desejam indicar a seus alunos, livros didáticos da melhor qualidade possível, dentro das circunstâncias existentes.

Finalmente, como refere OLIVEIRA ${ }^{38,} 39$, "os professores não escolherão bem se naõ puderem escolher nunca. E não o farão bem se não puderem discernir o que é melhor e não escolherão bem ainda se forem sistematicamente excluídos do processo de seleção. $O$ fascínio que uma publicação pode exercer por requintes de sedução gráfica só pode ser descartada por critérios qualitativos de competên. cia, de conhecimento, de preparo e de consciência profissional".

\section{1 - Os programas de Saúde}

A Lei no 5692 de 11 de agosto de $1971^{* 8}$ estabeleceu, em seu artigo $7^{\circ}$, que fosse obrigatória a inclusão, nos currículos de 10 e 20 graus, os Programas de Saúde. Pela primeira vez, a lei destacou e individualizou a "Educação da Saúde", efetivada pelo Parecer no 2264/74 do Conselho Federal de Educação**12. Este Parecer estabelece o conteúdo mínimo, sugerindo alguns assuntos que devem ser tratados na primera e segunda etapa do $1^{\circ}$ e no $2^{\circ}$ grau, porém aponta que este conteúdo deve ser coerente e inserido nas reais necessidades da comunidade, na faixa etária do aluno a que se destina. A escola deve ser um modelo quanto às práticas de saúde.

Desde então, houve a necessidade de serem criados livros de Programas de Saúde, com o objetivo de conterem, ao longo de todas as séries do $1^{\circ}$ e $2^{\circ}$ graus, 0 conteúdo programático estabelecido pelo Parecer acima citado.

Algumas cidades do Estado de São Paulo já haviam implantado desde 1968, uma área de estudo denominada área de saúde, na qual eram desenvolvidos certos tópicos do programa posteriormente implantado 55,56 .

\footnotetext{
* Documenta Brasflia, (129): 400-416, ago. 1971.

** Documenta Braślia, 13(165): 63-83, ago. 1974.
} 
Os livros-texto de Programas de Saúde, em especial os destinados ao ensino de $1^{\circ}$ grau, raramente são livros individuais que contêm apenas o conteúdo destes programas vindo, freqüentemente, como "apêndice" de um livro de Ciências. Os de $2^{2}$ grau constituem um pequeno conjunto de textos, alguns deles passíveis de críticas quanto à fidedignidade de conceitos, profundidade do conteúdo e outros requisitos.

Como o livro é um instrumento de consulta para quem o possui, ele pode constituir-se, em alguns casos, como uma das únicas fontes de conhecimento da população sobre saúde e doença. Ou mesmo as pessoas privilegiadas, que conseguem freqüientar as escolas de $1^{\circ}$ e $2^{\circ}$ graus tornam-se juntamente com os seus livros, os mediadores de mudanças nas práticas de saúde de suas famílias ${ }^{23,26}$.

A realização do presente estudo torna-se necessária pois os livros didáticos* de Programas de Saúde ainda permanecem pouco explorados, apesar de existirem inúmeros artigos e teses que se referem especialmente aos livros-texto da matéria** Ciências ${ }^{7,45}$ e das disciplinas*** Psicologia Educacional ${ }^{20}$, Biologia $^{2}$, Química $^{48}$, História ${ }^{21,58}$, Física ${ }^{34}$, Português ${ }^{3,6,28,33,44}$ e Matemática ${ }^{25,47 .}$

$\mathrm{Na}$ qualidade de diplomada em Ciências Biológicas e em Enfermagem, com experiência no ensino de Ciências, Biologia, Biologia Educacional e Programas de Saúde para alunos de nível médio, a autora deparou-se com problemas relativos aos textos de Programas de Saúde quanto aos aspectos de exatidão de informaçōes, de profundidade e de concordância com a legislação vigente. As discrepâncias mencionadas dificultam o processo ensino/aprendizagem levando, algumas vezes, a entendimentos distorcidos, fixaçāo de informaçōes errôneas e falsas interpretaçōes.

Pretende-se, com o presente estudo, alertar o professor que desenvolve o conteúdo de Programas de Saúde para que esteja voltado para os aspectos relevantes a serem considerados na escolha e indicação de um livro-texto, fornecendo um modelo para alterar o atual "estado de coisas" com relação a estes quesitos.

$\mathrm{Na}$ análise do conteúdo dos livros didáticos de Ciências e Programas de Saúde adotados nas primeiras séries do $1^{\circ}$ grau em Pernambuco, MARIZ ${ }^{26}$ identificou como formas de ideologização os seguintes elementos: valorização explícita do conhecimento científico, da racionalidade e do progresso tecnológico; o individualismo transmitido, indiretamente, pela valorização do papel dos "sábios ilustres", riquezas naturais e institutos de pesquisas nacionais; menor volume de

* Neste trabalho, utilizamos livro didático como sinónimo de livro-texto.

* Matéria: $€$ o indicativo de determinada ordem de conhecimento a ser explorada atraves de disciplinas, áreas de estudo e atividades que dela derivem. O Conselho Federal de Educação fixou como matérias Comunicaçăo e Expressāo, Estudos Sociais e Ciências 8 .

*** Disciplina: é o conjunto de conteúdo e experiência cuja origem se encontra em um determinado ramo do saber. É a Física, Química que são partes da matéria Ciências; e a História e Geografia, são partes de Estudos Sociais 8 . 
informaçōes sobre saúde e higiene em relação a outros assuntos; maior valorizaçāo das descobertas e invençōes que geram riqueza do que à saúde; omissão dos condicionantes sociais da saúde, dos malefícios da tecnologia e da diferença social de seus benefícios.

A mesma autora, num trabalho sobre o texto didático e criança carente ${ }^{27}$, analisou os livros de Comunicação e Expressão, Ciências e Programas de Saúde, e concluiu que os textos apresentavam impropriedades quanto: ao material escolar exigido e/ou sugerido; ao ambiente sócio-econômico onde vive a criança; a elementos sócio-lingüísticos e sócio-geográficos; às condições materiais da escola; ao preparo e condição de trabalho do professorado; e ao nível de aprendizado dos alunos. Criticou ainda, a ausência de critérios sociais que orientem a escolha e elaboração dos textos didáticos, bem como o processo de centralização em sua elaboração.

Um estudo realizado por MELO $^{30}$ demonstrou que o ensino de saúde no primeiro grau é feito assistematicamente, de maneira impositiva, fora da realidade do educando, o que os leva à reinterpretações. Não há um currículo escolar no qual a saúde possa se integrar. Para desenvolver o projeto, seria necessário a elaboração de um currículo escolar para a rede de ensino de primeiro grau integrando o ensino da saúde. É através do estudo do meio que o aluno pode apreender novas formas de se relacionar atingindo diferentes normalidades.

Em sua tese de doutoramento, SERBINO ${ }^{55}$ afirma que não são apenas os problemas econômicos que geram a falta de saúde, como também a privação educacional. Seu estudo, realizado em Botucatu, São Paulo, em todas as escolas de 10 grau (1 a a $4^{\mathrm{a}}$ séries), mostra que a rede escolar nada tem feito a este respeito. Os professores não receberam, na área de saúde, a formação pertinente às suas responsabilidades profissionais. $\mathrm{O}$ ensino que ministram é irrelevante em relação às necessidades reais. A escola, por suas condiçōes precárias, reforça negativamente os comportamentos favoráveis à saúde. Os órgãos centrais, com responsabilidade direta na área de assistência à saúde, além de não terem presença efetiva em todas as unidades escolares, têm suas açōes voltadas ao aspecto assistencial e curativo, descurando $o$ aspecto formativo.

Continua ainda afirmando ${ }^{55}$, que as famílias não têm sido incentivadas e orientadas pelas escolas, para assumirem os problemas de saúde das crianças. As instituiçōes de ensino devem tomar medidas urgentes para que possam atuar no campo da educação para a saúde.

As afirmações acima têm fundamentos lógicos pois a idade escolar é uma fase durante a qual o organismo deve contar com uma série de condiçōes favoráveis (alimentação, cuidados higiênicos, suporte afetivo) para que a criança possa obter um número considerável de aquisições que lhe são necessárias: físicas (crescimento e formação de hábitos), mentais (ajustamento ao meio ambiente, relaciona- 
mento) e emocionais (narmonıa de expressōes, sentimento de confiança, equilibrio emotivo $^{5,17,18}$.

Isto é confirmado por RODRIGUES ${ }^{46}$, ao escrever que a criança em etapa escolar está num período de muita receptividade, incorporando facilmente as práticas positivas de saúde e esta condição é imprescindível para que haja uma aprendizagem efetiva.

Educação da saúde "é mais do que uma disciplina especial: é uma atitude mental, uma maneira de pensar e agir, que utiliza os recursos das ciências médicas, pedagógicas, educacional e social" ${ }^{5}$ ". É "um processo de dimensōes intelectuais, psicológicas e sociais relativo a atividades que aumentam a aptidão das pessoas para adotarem decisōes conscientes que afetam seu bem-estar pessoal, familiar e comunitário" (JOHNS apud JORGE ${ }^{22}$ ).

O campo de abrangência da escola e dos meios educativos que ela utiliza é muito amplo, posto que não inclui apenas crianças e adolescentes, mas também adultos. Além disso, não se pode esquecer que, tanto através de crianças quanto de jovens e adultos, a escola é um centro irradiador para as famílias e para a comunidade.

A Escola, como instituição educacional, não pode esquecer da saúde; deve colaborar para que os indivíduos e a comunidade atinjam níveis de saúde compatíveis com o bem-estar que deve caracterizar a vida do ser humano. Esta colaboração vai além da assistência médica: abrange aspectos de preservação e promoção da saúde.

\section{OBJETIVOS}

Pretende-se com este trabalho, atingir os seguintes objetivos:

1 - Constatar a disciplina e a série do curso de $1^{\circ}$ e $2^{\circ}$ graus em que são desenvolvidos os Programas de Saúde e a formação do professor que ministra esta matéria.

2 - Analisar criticamente a exatidão e profundidade do conteúdo do livro-texto de Programas de Saúde utilizados nas escolas de $1^{\circ}$ e $2^{\circ}$ graus da cidade de São Paulo.

3 - Estabelecer critérios para a seleção e para a adoção dos referidos livros-texto pela elaboração de uma ficha analítica para avaliação de livros-texto.

4 - Comparar os aspectos comuns e os discordantes nos livros-texto referidos pelo professor que ministra os Programas de Saúde conforme ficha analítica elaborada. 


\section{METODOLOGIA}

O presente trabalho constituiu-se um Estudo Exploratório do tipo descritivo.

Escolhemos para realizarmos o presente estudo as escolas jurisdicionadas à 13a Delegacia de Ensino (D.E.) do Município de São Paulo, subordinada à DRECAP( $^{(*)}$-3. Esta delegacia tem sob sua jurisdição os seguintes subdistritos: Bela Vista, Cerqueira César, Consolação, Jardim América, Jardim Paulista, Pinheiros, Vila Madalena e Vila Mariana.

Escolheu-se esta Delegacia de Ensino pela proximidade física com a Escola de Enfermagem, como também pela interação existente com algumas escolas sob sua jurisdição, que servem de campo de estágio para as alunas de Prática de Ensino de Enfermagem do Curso de Licenciatura em Enfermagem da Faculdade de Educação e Escola de Enfermagem da Universidade de São Paulo.

A Delegacia de Ensino em questão consta de unidades escolares públicas e particulares assim divididas:

- públicas: 15 Escolas Estaduais de Primeiro Grau (E.E.P.G.); 03 de Segundo Grau (E.E.S.G.) e 06 de Primeiro e Segundo Graus (E.E.P.S.G.), totalizando 24 unidades;

- particulares: aproximadamente 240 , dentre elas berçários, conservatórios, escolas maternais, profissionalizantes, de ensino supletivo,... da.

Para fins deste estudo consideramos apenas as escolas públicas da D.E. cita-

$O$ instrumento utilizado para a coleta de dados nesta fase foi o questionário dirigido aos professores que ministram os Programas de Saúde. O questionário em questão (Anexo 1) está dividido em quatro partes e procura caracterizar o professor que ministra os Programas de Saúde, a matéria propriamente dita, os livrostexto adotados ou utilizados e algumas opiniōes do professor da referida matéria quanto ao processo de seleção e adoção de livros-texto.

A aplicação do instrumento foi realizada nos meses de novembro e dezembro de 1986 pela própria autora do trabalho junto às escolas públicas da 13ª Delegacia de Ensino, de acordo com a seguinte sistemática:

- contato pessoal com os diretores das unidades escolares, a fim de obter autorização para a coleta de dados;

- distribuição dos questionários aos professores de Programas de Saúde;

- retorno às escolas após período estipulado, para recolhimento dos questionários respondidos.

(*) DRECAP: Delegacia Regional de Ensino da Capital. 
Das vinte e quatro escolas estaduais que compuseram a amostra, quatro $(16,7 \%)$ não participaram da coleta de dados: uma por não autorização da Diretora do estabelecimento $(4,1 \%)$ e três $(12,5 \%)$ por recusa dos professores em fazê-lo.

Dos setenta e três questionários entregues, apenas $42(50,6 \%)$ foram devolvidos devidamente respondidos.

Os dados obtidos através do questionário foram tabulados para dar uma visão global dos ítens referidos na descrição do instrumento e os resultados apresentados em freqüência absoluta e relativa (\%).

Os livros-texto de Programas de Saúde indicados nos questionários respondidos pelos professores foram solicitados às casas publicadoras responsáveis pela edição dos mesmos.

É necessário ressaltar que, dentre as editoras referidas como publicadoras dos livros mencionados, uma mudou-se e não nos foi possível encontrar sua nova locação; três, não responderam ao nosso pedido ficando, portanto, cinco referências sem nos serem enviadas; e outras oito, não pudemos encontrar a editora que as publicava.

Uma vez tendo recebido os referidos exemplares, sentimos a necessidade de elaborar uma ficha analítica para avaliação dos livros-texto, já que as existentes não nos satisfizeram em relação a alguns aspectos a serem analisados e que, portanto, não nos permitiu utilizá-las na íntegra.

Resolvemos, então, fazer uma adaptaçāo inédita a partir das fichas analíticas existentes, e optamos pelo padrão de preenchimento do tipo "checksheet" $* 42$, em que os quesitos de cada aspecto a ser avaliado é checado no espaço imediato à sua menção. (Anexo 2).

\section{4 - APRESENTAÇĀO E DISCUSSĀO DOS DADOS}

Com a finalidade de facilitar a compreensão do estudo, a apresentação e discussão dos dados foi feita conjuntamente, obedecendo a seguinte sistemática: ítens do instrumento de coleta de dados e análise dos livros didáticos recebidos pela autora do presente trabalho.

4.1 - Apresentação e discussão dos dados do questionário

É importante conhecer a formação profissional do docente que ministra os Programas de Saúde, pois este fato irá influir, diretamente, na seleção de temas para desenvolvê-los.

* Checksheet: folha de preenchimento. 
Observamos que dentre os professores que ministram os Programas de Saúde, $27(62,79 \%)$ possuem o curso de licenciatura em Ciências Biológicas, 5 $(11,63 \%)$ a graduação em História Natural* e os onze demais possuem, além da licenciatura em Ciências e/ou Ciências Biológicas, cursos complementares, tais como Pedagogia e Ciências Sociais.

A totalidade dos professores que desenvolvem os Programas de Saúde são professores de Ciências e/ou Ciências Biológicas.

Conforme o Parecer CFE no 2264/74 12 “os temas do programa de saúde devem ser tratados nas disciplinas em que couberem, no currículo de $2^{\circ}$ grau dos cursos de habilitação ao magistério e, principalmente, nas licenciaturas em Ciências, Estudos Sociais, Educaçāo para o lar e Educaçāo Física, e nos cursos de graduação da área biomédica".

"No primeiro estágio do $1 \%$ grau, a própria professora de classe deverá estar habilitada a desenvolver os programas de saúde. No segundo estágio desse tipo de ensino (5⿳亠丷a a $8^{a}$ série) e no de $2^{\circ}$ grau, esses programas deverāo ser ministrados por professores com formação universitária, habilitados em qualquer das várias áreas do ensino"12.

É necessário ressaltar que na descrição do mesmo Parecer há referência quanto à falta de professores preparados para o planejamento e desenvolvimento de Programas de Saúde. Isto não é verdadeiro pois, como pudemos observar anteriormente, nāo são só os professores de Ciências e/ou Ciências Biológicas que podem desenvolver esta matéria. Professores de Estudos Sociais, Educação para o lar, Educação Física ou de qualquer disciplina da área biomédica estão habilitados para tal.

No momento é oportuno lembrarmos da Resolução CFE № 4 de 25-02-72 no parágrafo único do artigo 7ㅇ: "Ao enfermeiro que receber, em estudos regulares a formação pedagógica prescrita para os cursos de licenciatura, será concedido o diploma de licenciado em Enfermagem com direito ao registro definitivo como professor, ao nível de $1^{\circ}$ e $2^{\circ}$ graus, das disciplinas e atividades relacionadas à Enfermagem, Higiene e Programas de Saúde ${ }^{16 "}$.

O dispositivo legal é claro e habilita o enfermeiro a lecionar em Programas de Saúde. Se a enfermagem não o faz é porque existem razões para justificar este fato $^{11,13,15}$.

Trinta e três professores que ministram os Programas de Saúde, $(76,74 \%)$ (33) terminaram a licenciatura em período anterior a 1977, de onde se deduz que já são licenciados há dez anos ou mais; seis professores $(13,95 \%)$ são praticamente recém-formados e quatro $(9,30 \%)$ têm de seis a dez anos de licenciatura.

* O curso de História Natural é hoje denominado Ciências Biológicas 
Aqui surge a dúvida: será que estes professores com mais de seis anos de licenciados (podendo inclusive serem graduados há muito mais tempo) fizeram ou têm feito algum curso de atualização, reciclagem ou aperfeiçoamento, a fim de melhor se capacitarem para desenvolverem seus cursos? Progressos científicos e pedagógicos estão ocorrendo dia após dia, fato este que justifica a necessidade deste aperfeiçoamento.

Convém ressaltar que o professor licenciado possui, além da formação específica numa determinada área de conhecimento, a formação pedagógica a ela relacionada.

A reciclagem a que nos referimos seria feita na área de saúde, uma vez que o professor que ministra os Programas de Saúde dificilmente tem a formação específica para tal.

Cabe lembrar novamente, a capacitação que a enfermeira tem para desenvolver os Programas de Saúde, já que seu currículo mínimo prevê disciplinas básicas que subsidiariam o desenvolvimento desses Programas.

O problema da ausência de reciclagem é também sentidp na área de Comunicação e Expressão como refere PONDÉ et alii ${ }^{44}$.

Segundo o Parecer CFE no 2264/74 "Será indispensável a colaboração dos serviços de saúde da comunidade e a participação de todos os elementos aptos a trazer contribuição ao assunto visando a criação de agências de preparação de material e de treinamento ou aperfeiçoamento de pessoal docente, não só dos professores em exercício como dos alunos dos cursos de habilitação ao magistério de 19 e $2 \%$ graus ${ }^{12}$.

"Para o aperfeiçoamento do professorado a curto prazo, caberá começar por cursos de treinamento, atualização e aperfeiçoamento oferecidos a professores selecionados, capazes de se tornarem agentes de inovação, os quais se incumbirão de multiplicar os cursos de capacitação em áreas semelhantes ${ }^{12}$ ".

Das escolas que fizeram parte de nossa amostra, $37(86,05 \%)$ não possuem os Programas de Saúde como matéria independente* estando ligados às disciplinas Ciências e Ciências Biológicas.

Novamente nos reportamos ao Parecer CFE no 2264/74, que reza “... se impõe a correlação dos diversos conteúdos programáticos, especialmente daqueles ligados às áreas de Ciências, de Estudos Sociais e Educação Física,..."12

"A escola deve possuir seu programa de saúde individualizado, indicando em que área de estudo ou disciplina será desenvolvido cada tema". ${ }^{12}$

\footnotetext{
* será utilizada a expressão "matéria independente" significando que não é ministrada isoladamente e sim, vinculada às disciplinas Ciências ou Ciências Biologicas.
} 
Mais uma vez surge a interrogação: Por que só os professores de Ciências e/ou Ciências Biológicas é que estão no magistério dos Programas de Saúde?

Estando delimitada a formação profissional dos docentes que ministram os Programas de Saúde, o período em que se licenciaram, as disciplinas que lecionam e aquelas que desenvolvem os Programas de Saúde, é válido demonstrarmos em que séries são ministrados e a carga horária semanal a eles destinada.

Pudemos verificar que doze escolas - dez de $1^{\circ}$ grau e 2 de $1^{\circ}$ e $2^{\circ}$ graus, respectivamente $83,34 \%$ e $50 \%$ ministram os Programas de Saúde em todas as séries da segunda etapa do $1^{\circ}$ Grau $\left(5^{\mathrm{a}}\right.$ a $8^{\mathrm{a}}$ ); três escolas - uma de $1^{\circ}$ grau e duas

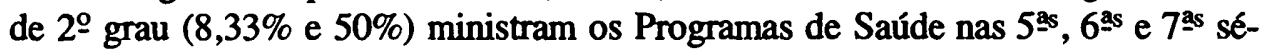
ries; outras três escolas - duas de $2^{\circ}$ grau e uma de $1 \%$ e $2 \%$ graus $(75,0 \%$ e $25 \%$ respectivamente) desenvolvem os Programas de Saúde em todas as séries do 2o grau ( $1^{\text {a }}$ a $\left.3^{a}\right)$. O restante das escolas que compuseram a amostra, ministram os Programas de Saúde em alguma(s) série(s) do $1 \%$ e/ou $2^{\circ}$ Graus.

Não há referência no Parecer ( $\left.\mathrm{n}^{\circ} 2264 / 74^{12}\right)$ sobre a distribuição da matéria nas diferentes séries do $1^{\circ}$ e $2^{\circ}$ graus; apenas são mencionados os conteúdos que devem ser ministrados em cada etapa do ensino médio.

O referido Parecer estabelece que "a profundidade dos conhecimentos ensinados, a intensidade e a extensão das atividades são condicionadas pelos recursos didáticos e o nível de desenvolvimento local ${ }^{12}$.

“Os Programas de Saúde devem ser organizados a nível de escola para que se torne realmente pragmático, realístico e útil em cada localidade ${ }^{12}$ ".

Consideramos que os Programas de Saúde devem ser ministrados em todas as séries do $1^{\circ}$ e $2^{\circ}$ graus, abordando assuntos diversos em cada uma delas, aumentando o grau de complexidade a medida que o aprendizado evolui.

Verificamos que, na grande maioria das escolas não há carga semanal destinada aos Programas de Saúde quer no 1ำ, quer no $2^{\circ}$ grau $(31-72,09 \%$ e 20 $46,51 \%$, respectivamente). Portanto, as aulas são dadas em situações ocasionais.

Seis escolas - três de $1^{\circ}$ grau e três de $2^{\circ}$ grau, ministram uma aula semanal de Programas de Saúde; seis escolas de $2^{\circ}$ grau, ministram duas aulas semanais dos referidos programas.

"A fixação do número de horas e a distribuição dos conteúdos programáticos, consideradas sua oportunidade e motivação, são de competência de cada estabelecimento de ensino ${ }^{12 ", .}$

Como o Parecer em questão não estabelece o número de horas/aula destinadas aos Programas de Saúde, cria-se um problema (disparidade entre as escolas), sentido pelos professores questionados, que sugerem maior carga horária dos Programas de Saúde como matéria independente e ministrados em todas as séries, principalmente no $2^{\circ}$ grau. 
Retomando o objetivo deste estudo, verificamos que a adoção de livro-texto para desenvolver os Programas de Saúde é feita por 21 escolas - 48,84\% e a não adoção, por 20 escolas - 46,51\%. Como pode ser observado há quase uma coincidência entre as duas posiçōes.

Isto pode ser atribuído às seguintes opiniōes emitidas pelos professores com relação ao livro-texto de Programas de Saúde: a) deve ser completo, adequado à série a que se destina; b) deve veicular conteúdo prático e realista; c) possuir metodologia moderna, linguagem agradável e fácil; d) modificar as patologias abordadas.

Quando o livro-texto é adotado, dificilmente possui apenas o conteúdo referente aos Programas de Saúde: 15 professores 62,50\% referem que não adotam livro-texto com conteúdo exclusivo destes Programas. Esta deve ser provavelmente, a opinião emitida pelos professores de $1^{\circ}$ grau*, pois são os livros-textos de Ciências que possuem uma parte ou alguns capítulos referentes aos Programas de Saúde.

Será que os professores pesquisados possuem um instrumento para avaliação do livro-texto de Programas de Saúde? Vinte e oito professores $-65,12 \%$ referem a utilização de algum tipo de instrumento. Não foi especificado por eles qual é este instrumento, uma vez que esta informação não foi pesquisada pelo questionário.

Pode ser inclusive que este instrumento de avaliação seja o estabelecido pela Resolução CFE no 113/76, já referida anteriormente.

Com relação ao livro-texto de Programas de Saúde é necessário conhecermos quais os aspectos considerados preponderantes pelo professor na seleção e adoção dos mesmos.

Verifiçamos que 20 professores - 43,49\% mencionam o conteúdo como aspecto preponderante na seleçāo do livro-texto de Programas de Saúde; dez professores - $21,74 \%$ referem conteúdo e linguagem e oito - 7,39\%, conteúdo, linguagem e aspectos técnico-gráficos. Este dado representa que $82,62 \%$ dos docentes pesquisados, mencionam o conteúdo como um aspecto básico a ser considerado na selação de livro-texto de Programas de Saúde.

Da mesma forma, o conteúdo é considerado aspecto prioritário na adoção de livros-texto de Programas de Saúde: 18 professores - 38,30\% consideram somente este aspecto; sete professores - 14,89\%, conteúdo e linguagem e cinco - 10,64\%, conteúdo, linguagem $e$ aspectos técnico-gráficos.

\footnotetext{
* Um livro de Biologia mencionado (2 grau) é utilizado para o desenvolvimento dos Programas de Saúde.
} 
É necessário ressaltar que os professores pesquisados conhecem a importância do conteúdo veiculado num livro-didático, pois como afirma CREIDY ${ }^{19}$ "o professor deve escolher um livro-texto que a auxilie em seu trabalho, bem como tem desejo de ter um livro que torne a aprendizagem de seus alunos mais rápida $\mathrm{e}$ eficiente".

Outros autores também referem a importância do conteúdo do livro-texto, entre eles MENEGALE ${ }^{31}$ e PFROMM NETO et $\mathrm{alii}^{41}$.

"Os livros são desatualizados, heterogêneos, focalizando um conhecimento irrelevante, distante de nossos problemas educacionais e das necessidades do professor..." 31

"A proliferação de textos de baixa qualidade soma-se a frequêencia com que, em diferentes níveis de ensino, decisões graves e irreversíveis são tomadas a partir de critérios pessoais subjetivos, indiferentes ou ostensivamente opostos a tudo quanto se sabe, a respeito do livro didático e do seu emprego no ensino ${ }^{40}$ ".

Dos livros referidos e recebidos das editoras após solicitação, verificamos que nem todos possuem o conteúdo dos Programas de Saúde, apesar do título de alguns deles assim o referirem.

4.2. - Apresentação e discussão dos dados das fichas analíticas para avaliação de livros textos.

Passaremos a analisar o conteúdo dos livros-texto de Ciências com parte específica referente aos Programas de Saúde e os livros didáticos de Programas de Saúde mais utilizados, a partir dos resultados obtidos nesta pesquisa.

Os livros-texto analisados estão referidos no Quadro 1. (na página seguinte)

A comparaçāo entre os livros-texto de Programas de Saúde, aponta os seguintes quesitos em comum:

1. QUANTO AO CONTEÚDO:

- relevância dos temas abordados e

- não relaçāo com outras disciplinas.

2. QUANTO AOS EXERCÍCIOS:

- estreita relação com o conteúdo veiculado;

- quantidade adequada;

- pouca graduação de dificuldade; $e$

- raro estímulo à criatividade do aluno ao desenvolvê-los.

3. QUANTO ÀS ILUSTRAÇŌES:

- constituirem-se fundamentalmente de estampas.

4. QUANTO AOS ÍNDICES:

- haver índice de capítulos e assuntos. 


\section{QUADRO 1}

\begin{tabular}{|c|c|c|c|c|}
\hline $\begin{array}{l}\text { Código do livro-texto } \\
\text { Número da ficha analítica }\end{array}$ & $\begin{array}{c}\text { AUTOR } \\
\text { Número da referência } \\
\text { bibliográfica especializada }\end{array}$ & TÍTULO & SÉRIE & DATA \\
\hline 1 & $\begin{array}{c}\text { ENS, Waldemar e } \\
\text { LAGO, S.R. } \\
1\end{array}$ & $\begin{array}{l}\text { Ciências: a terra: o meio } \\
\text { ambiente e os recursos } \\
\text { naturais-saúde }\end{array}$ & 5 & s.d.* \\
\hline 2 & $\begin{array}{c}\text { FERNANDES, Napoleão } \\
\text { Lima e CARVALHO, Odair } \\
\text { Barros } \\
3\end{array}$ & $\begin{array}{l}\text { Estudando o ambiente: } \\
\text { programas de saúde e ecologia }\end{array}$ & $5:$ & s.d.* \\
\hline 3 & $\begin{array}{l}\text { idem } \\
2\end{array}$ & $\begin{array}{l}\text { Estudando a energia: } \\
\text { programas de saúde e ecologia }\end{array}$ & $8^{\mathrm{a}}$ & s.d.* \\
\hline 4 & $\begin{array}{c}\text { LOPES, Plínio Carvalho } \\
4\end{array}$ & O ambiente: ciências e saúde & $5=$ & 1986 \\
\hline 5 & $\begin{array}{c}\text { MARCONDES, Ayrton César } \\
5\end{array}$ & Programas de Saúde & $2^{\circ}$ grau & 1983 \\
\hline 6 & $\begin{array}{c}\text { VILELA, Carlos Ribeiro, } \\
\text { NOVAIS, Luis Antonio } \\
\text { Lima, NOVAIS, Vera Lucia } \\
\text { Duarte } \\
6\end{array}$ & Ciências e Programas de saúde & 6a & 1977 \\
\hline 7 & $\begin{array}{c}\text { idem } \\
7\end{array}$ & idem & $7 \mathrm{a}$ & 1977 \\
\hline 8 & $\begin{array}{l}\text { idem } \\
8\end{array}$ & idem & $8=$ & 1977 \\
\hline 9 & $\begin{array}{c}\text { ZEINUM, Renato } \\
9\end{array}$ & $\begin{array}{l}\text { Ciências: corpo humano: } \\
\text { saúde e ecologia }\end{array}$ & $7 \mathrm{a}$ & s.d.* \\
\hline
\end{tabular}

* s.d.: sem data 
A diferença mais marcante é a falta de atualização de informações transmitidas, deficiência na precisão científica das mesmas, e o grande número de erros gramaticais: de concordância verbal e nominal, ortográficos e de pontuação.

Todos os livros-texto de Programas de Saúde analisados preocupam-se com a legibilidade do texto pois apresentam papel branco, não brilhante, bom espaçamento entre as linhas e a existência de parágrafos.

Quanto à ORGANIZAÇÃO DO CONTEÚDO, notamos que nenhum dos livros-textos analisados possuem quadro sinótico, optando por formas de conclusão mais elaboradas, tais como o resumo e o sumário.

Em relação à APRESENTAÇĀO DO CONTEÚDO verificamos que todas as informaçōes abordadas são relevantes, apesar de pouco exploradas ou mesmo com redação monótona.

Os assuntos discutidos nos livros-texto em estudo mostram-se repetitivos ao longo das quatro séries da segunda etapa do primeiro grau ( $5^{\mathrm{a}}$ a $8^{\mathrm{a}}$ séries). São eles:

- 5e série*

poluição do ar: 3 livros-texto;

poluição da água: 3 livros-texto;

poluição do solo: 3 livros-texto;

saneamento básico: 1 livro-texto;

higiene física, mental e social: 1 livro-texto; e

doenças causadas por vírus: 1 livro-texto.

- 6⿳⺈ série**

alimentos e fator econômico;

dieta equilibrada;

distribuição de alimentos;

poluição da água;

tratamento do lixo;

vacinas e soros; $\mathrm{e}$

tuberculose.

* São três os livros-tex to de Programas de Saúde analisados.

** Apenas um livro-texto destinado a esta série foi analisado. 
- 7 série*

Glândulas endócrinas;

os dentes;

tratamento e abastecimento de água;

tratamento dos esgotos;

segurança de trânsito;

álcool; e

higiene corporal.

- 8 série**

química e alimentos;

tratamento do lixo;

poluição das águas;

concepção e evolução do ser humano;

aparelho reprodutor masculino e feminino;

fecundação, gestação e parto;

alimentação familiar;

saneamento básico; e

cobras, piolhos e chatos.

Com a exposição acima, notamos que alguns assuntos tais como poluição da água, são abordados em três das quatro séries e saneamento básico discutido em duas das quatro séries.

De acordo com o material informativo, elaborado pela Coordenadoria de Estudos e Normas Pedagógicas (CENP) ${ }^{49}, 50,51$, vários são os assuntos que deveriam ser estudados nas diferentes séries, agrupados em torno de quatro temas básicos: crescimento e desenvolvimento; nutrição; higiene física, mental e social; e agravos à saúde.

Com isso percebemos que somente o tema higiene física, mental e social é abordado na grande maioria dos livros-texto de Programas de Saúde analisados. Apenas a coleção composta pelos livros-texto 6, 7 e 8 abordam um assunto referente a cada tema básico.

Os capítulos referentes aos Programas de Saúde nos livros-texto de Ciências são sempre relacionados ao conteúdo desta matéria de acordo com a série a que se destina sendo, portanto, estanques, sem relação intrínseca entre eles.

* Apenas um livro-texto destinado a esta série foi analisado.

** Dois livros-texto de Programas de Saúde destinados a esta série foram analisados. 
Com relação ao único livro-texto de Programas de Saúde analisado e referente ao ensino de segundo grau, verificamos que a grande maioria dos assuntos relacionados na proposta curricular da CENP ${ }^{49}$ são estudados.

Com referência ao CONTEÚDO dos livros-texto de Programas de Saúde, observamos que não há relação deste com outras disciplinas, fato este desfavorável uma vez que determinados assuntos podem ser complementados em outras matérias, tais como Estudos Sociais.

Os EXERCÍCIOS são parte importante dentro de um livro didático. Constatamos que, em todos os livros-texto analisados, há relação direta dos exercícios com o conteúdo, quantidade adequada dos mesmos, rara graduação de dificuldades e nenhum estímulo à criatividade do aluno ao desenvolvê-los.

Este quesito é analisado por PFROMM NETO et alii ${ }^{41}$ " .... textos, exercícios e questōes colocados em linguagem compreensível e com crescimento progressivo de dificuldades permitem que o estudo ocorra sem risco de malogro e ajudam o leitor muito jovem a considerar a leitura como uma experiência que causa prazer. Os exercícios e questões propostas pelo livro didático deve ser bastante objetivos, estar relacionados diretamente com a matéria exposta, ser adequados ao nível dos alunos a que se destinam e permitir oportunidades de raciocínio e expressāo".

Isto não ocorre com os livros-texto de Programas de Saúde em estudo. Os exercícios são de pura memorização. Muitas vezes referem-se a algo que não aborda, e a ausência deste conteúdo, leva o aluno a responder sem ter o conhecimento do que está respondendo e o porquê de sua resposta. Ou ainda: o exercício contradiz o texto.

As atividades sugeridas ao aluno são meras repetições do texto apresentado. Eles terão apenas o trabalho de copiar o que já está escrito no texto, que por sua vez pode ser muito vago.

Os modelos de exercícios restringem-se aos tipos: associação, certo e errado, completamento, escolha múltipla, palavras cruzadas e questões breves.

Nas questões certo e errado, há mais afirmaçōes certas do que erradas, o que não é favorável ao espírito crítico e discernimento dos alunos. Deve haver $60 \%$ de afirmaçōes falsas para $40 \%$ de corretas $^{29}$.

Há mistura dos tipos de exercícios, o que não é conveniente pois dificulta o processo de adaptação mental a cada um deles, já que há um exercício de cada tipo seguido um ao outro ${ }^{29}$.

Há também mistura dos assuntos nos exercícios, ou seja, ao invés de as perguntas sobre um determinado aspecto virem juntas, elas vêem espalhadas ao longo do trabalho. cadeia.

Alguns exercícios podem ser respondidos por exclusāo ou haver o erro em 
Há falhas nas instruçōes de alguns exercícios ou mesmo construção inadequada dos mesmos.

Referente às ILUSTRAÇÕES, elas são compostas basicamente por estampas. Apenas um dos livros-texto analisados possui mapas e gráficos. Vários deles possuem esquemas.

Este quesito será melhor explorado posteriormente.

As REFERÊNCIAS BIBLIOGRÁFICAS são de grande utilidade para o professor, no preparo de aulas, no preparo pessoal como também em seu aperfeiçoamento e aprofundamento no assunto. Há porém desatualização das mesmas, uma vez que se referem a período anterior a 1977: portanto, mais de dez anos decorreram em relação aos dados apresentados.

Os ÍNDICES de capítulos e assuntos são muito úteis pois facilita a procura dos mesmos no livro didático.

Daqui em diante, iremos alterar a ordem de análise dos quesitos, a fim de melhor focalizarmos o aspecto fundamental deste estudo que é a avaliação do conteúdo dos livros-texto de Programas de Saúde.

Como referido anteriormente os capítlos não têm encadeamento lógico por possuírem estreita relação com o conteúdo de Ciências de uma série determinada do primeiro grau. No livro-texto de Programas de Saúde destinado ao segundo grau, este fato já não ocorre, havendo respeito à seqüência lógica dos assuntos.

Cinco dos livros-texto analisados são possuem nenhuma forma de síntese do conteúdo, quer seja sob a forma de resumo, sumário ou quadro sinótico.

Como afirma PFROMM NETO et alii ${ }^{41}$ : "o conteúdo deve se constituir num todo unificado. Suas várias unidades devem estar interligadas, formando uma seqüência coerente e compreensível. Para esta integração, contribuem muito as sínteses, conclusões e sumários que muitos livros trazem ao fim ou início de cada capítulo ou unidade".

O estilo literário dos livros-texto analisados é, na grande maioria deles, monótono, enfadonho e cansativo, com redação inadequada, apresentando informaçōes truncadas semelhante a um receituário; não há seqüência lógica no desenvolvimento de alguns parágrafos, há frases escritas na ordem indireta, como também o uso de linguagem infantil, com repetição de palavras e infelizmente, o tratamento suscinto de temas de capital importância no ensino de saúde.

Relativa à correção gramatical, verificamos que há inúmeras incorreçōes: erros ortográficos, de pontuação, de regência verbal, termos técnicos ou siglas sem o devido esclarecimento ou mesmo usados incorretamente.

Quanto ao vocabulário, notamos que, de um modo geral, está adequado ao nível do aluno, relativo a seu cotidiano. Porém, algumas vezes, observamos que o vocabulário é complexo para o aluno da série a que o livro-texto se destina. 
Apenas um livro-texto analisado veicula "estereótipos", ao mencionar o uso de cotonetes para higiene do conduto auditivo externo, o que não é aconselhável, pois este instrumento faz com que a cêra, normal para o ouvido, seja empurrada mais profundamente nesta estrutura, podendo causar distúrbios.

As informações muitas vezes são defasadas, o que desmerece o conteúdo do texto em questão. Por exemplo: o uso de latas de lixo, que há muito tempo por questões higiências, foi substituído pelos sacos de lixo; o termo Light, hoje Eletropaulo; os dados sobre o tétano; o esquema de vacinação anterior a 1982; os testes diagnósticos de gravidez, que o livro-texto apenas se refere ao exame de urina, quando hoje o mais preciso e rápido é o da dosagem do hormônio gonadotrófico (B-HCG); uso incorreto da nomenclatura anatômica: o termo trompa de Falópio é chamado, atualmente, de tuba uterina; tabelas anteriores a 1977,...

Há também veiculação de informaçōes perigosas e, principalmente erradas, tais como: o uso de inseticida na pediculose, produto este que é tremendamente tóxico; hoje já existem produtos sob a forma de loção ou mesmo sabonete que têm a capacidade de matar piolhos e lêndias; o incentivo ao desmame do bebê; não abordagem, em nenhuma instância, da necessidade de assistência médica adequada no tratamento das doenças; a lavagem auditiva quando há problemas no ouvido: isto só é feito em consultório médico por profissional competente para tal.

Quanto à precisão científica, ocorrem muitas falhas devido à desatualização das informações. Há generalizaçōes incorretas e não há definição de alguns termos.

As informações essenciais são ressaltadas pelo negrito e por quadros coloridos ou não.

Um dado adicional: os autores utilizam, com muita frequiência, advérbios de tempo que não delimitam o período a que se referem.

"*Uma importante característica dos livros, principalmente os didáticos, é a inteligibilidade do texto: propriedade que o material escrito deve possuir para facilitar a compreensão de quem o lê.

O conteúdo apresentado deve crescer em complexidade, à medida que aumenta o grau de aprendizagem dos alunos. Este conteúdo não deve se limitar estritamente aos programas previstos pelos órgãos oficiais. É preciso, também, que tenha novas informaçōes, novas experiências, novos vocábulos, de modo a possibilitar contato cada vez maior com novos conceitos, novas descobertas, situações atuais.

\footnotetext{
* adaptado de PFROMM NETO et alii41
} 
Uma linguagem simples e agradável, além de despertar interesse, facilita extraordinariamente a transmissão de conhecimentos, valores e regras de procedimento.

Nos estudos relatados por Klare apud MOLINA ${ }^{32}$, os fatores de inteligibilidade mais destacados com relação aos livros são o fator palavra e o fator sentença. $O$ fator palavra é importante para sabermos se um livro apresenta maior ou menor inteligibilidade, em função da verificação do grau em que as palavras impressas estão entre as mais freqüentemente empregadas pela população. As palavras usadas num texto para ensino de $1^{\circ}$ grau devem estar entre aquelas mais usadas comumente por crianças ou jovens, para que sejam rapidamente reconhecidas e entendidas.

Isto não deve levar ao extremo de se esperar que o livro contenha apenas palavras conhecidas pelos alunos. Novas palavras e expressões devem aparecer, dentro dos limites impostos pelo nível de desenvolvimento desejado para o aluno ou dentro de contextos familiares aos leitores. Essas palavras novas, representando conceitos e idéias desconhecidas, devem obedecer também a certas regras de inteligibilidade. $\mathrm{O}$ reaparecimento dessas palavras, em contextos diversificados, no decorrer do livro facilitará a inteligibilidade. A esse fator os especialistas denominam de redundância. A avaliação do fator palavra depende, como se pode perceber, do conhecimento que temos do vocabulário básico, isto é, do conjunto de palavras mais freqüentemente usadas pela população a qual pertencem os leitores.

Outro aspecto de inteligibilidade refere-se à extensão das palavras. Quanto mais extensas as palavras, mais difíceis são elas, do ponto de vista da compreensāo.

Textos que apresentam sentenças ou períodos longos sāo menos inteligíveis que textos com frases curtas. É lógico que alunos mais adiantados podem compreender períodos mais longos melhor do que alunos menos avançados. Além disso é necessário verificar se os períodos longos nāo apresentam expressōes que contribuem para a redundância das idéias como "isto é", "em outras palavras", "quer dizer", "isto significa", pois tais recursos podem aumentar a facilidade de compreensão.

Além do fator palavra e do fator extensão dos períodos, ainda existe o problema da estrutura das oraçōes. Estudos mostram que há mais inteligibilidade quando as orações estão na voz ativa e quando se observa uma seqüência sujeitoverbo-complemento. Períodos em ordem indireta ou com verbos na voz passiva tendem a ser mais difícies.

O próprio tamanho de cada lição, capítulo ou unidade tem relevância para a compreensão. 
Estes fatores em conjunto, afetam significativamente a eficiência da leitura, a aceitação e o agrado do texto lido. Por isso, não podem passar desapercebidos pelo autor de livros didáticos, nem pelo professor ${ }^{41}$.

De um modo geral, o conteúdo é adequado ao nível do aluno; às vezes substimá-o; há poucas aplicaçōes práticas e raro estímulo à criatividade; é pouco desenvolvido, o que dificulta o entendimento. Em um dos livros-texto analisados, há motivação para leituras complementares e observaçōes pois, ao final de cada capítulo existem sugestōes para pesquisa, porém estas são puramente teóricas e não favorecem o espírito crítico do aluno.

"Bons livros-texto simplificam e interpretam em linguagem compreensível pelo aluno conteúdos que, em suas formulaçōes originais, se destinam a um reduzido número de especialistas; organizam e estruturam melhor esse conteúdo e fazem-no usando recursos tipográficos e de ilustração que facilitam o processo de aprendizagem $^{41}$.

Em relação ao quesito EXERCÍCIOS, observamos que cinco livros-texto possuem caderno de atividades (ou livro de exercício) que suplementam os exercícios do livro-texto. Nele encontramos, ao final de cada capítulo, uma série de questões cujas respostas encontram-se no texto.

No caderno de atividades, como já comentado anteriormente, encontramos uma variedade de tipos de exercícios: escolha múltipla, associação, completamento, seleção, certo e errado e palavras cruzadas.

Os livros-texto, que não são suplementados por um caderno de atividades, possuem questões breves ao longo ou ao final do capítulo, e alguns, outros tipos de questões.

A existência de um caderno de atividades faz com que o livro-texto não se torne descartável ou consumível, pois não há preenchimento dos exercícios propostos.

Vamos agora discutir, o quesito ILUSTRAÇŌES.

A maior parte das ilustrações não possui legendas, o que dificulta, algumas vezes, o entendimento do que ela significa ou mesmo que relação tem com o texto em questão.

Apenas um dos livros-texto analisados possui gráficos e mapas; um outro apenas, gráfico e dois outros, apenas esquemas, além de todos eles possuirem estampas, como já referido.

De um modo geral, a quantidade de ilustrações é adequada, porém algumas vezes, há necessidade de uma ilustração para esclarecer ou mesmo complementar o texto, e esta não existe. 
Referente à objetividade das ilustraçōes verificamos que, a maior parte delas são objetivas. Mas, com relação ao valor, verificamos que há muitas deficiências: apresentam incorreçōes (falhas, tais como setas apontando locais que não correspondem à nomenclatura estabelecida, desenhos desproporcionais, falta de dados e detalhes,...); não têm relação com o texto, não há nitidez, o que as tornam irreconhecíveis; são confusas ou não respeitam a seqüência lógica.

As ilustraçōes (estampas) são de relativa atratividade, pois muitas delas são feitas em preto e branco ou mesmo cinza, preto e branco o que gera monotonia, falta de atratividade da mesma.

Como refere PFROMM NETO et alii ${ }^{41}$, a integração dos textos com ilustraçōes é um dos recursos mais poderosos para aumentar o interesse, a compreensão, a aprendizagem e a retenção por parte dos alunos.

Segundo Smith \& Dechant apud PFROMM NETO ${ }^{41}$, a integração da parte verbal do texto com ilustraçōes pode fornecer o necessário realismo ao conteúdo, colaborar para a maior participação ativa do leitor e dar maior organizaçāo e estrutura aos conhecimentos, habilidades, atitudes e valores comunicados verbalmente. Em outras palavras, é preciso distinguir duas funçōes das ilustrações: a função informativa e a função de apoio ao processo de aprendizagem.

Essas duas funções podem ser desempenhadas por uma mesma ilustração, porém o professor, ao analisar um livro-texto deve verificar, se há integração das mesmas com o texto e se as ilustrações desempenham o papel que devem desempenhar. Um desenho ou um esquema sem legendas, sem clareza, sem contraste de tons e cores é tão criticável quanto um período muito longo, em ordem inversa, com verbo na voz passiva e repleto de palavras novas e difíceis. Ilustrações irrelevantes, sem integração com o texto escrito, podem inclusive prejudicar a compreensão e criar confusão na mente do aluno.

O professor não deve se iludir com a riqueza, a beleza e a cor da ilustração. O importante é o grau de realismo, o sentido de profundidade e perspectiva presente nos seres e objetos ilustrados, assim como a funcionalidade das mesmas.

Por isso o professor deve encarar as ilustraçóes de um texto com o mesmo cuidado que tem para com a parte escrita; isto quer dizer que existem problemas de legibilidade, planejamento gráfico e inteligibilidade que devem ser considerados.

"Quanto ao planejamento gráfico, as ilustraçōes devem obedecer a certos critérios de colocação. Elas devem entrar naturalmente sem prejudicar o desenrolar natural de uma leitura compreensiva nem exigir do leitor esforços desnecessários $^{41}$. Apenas dois dos livros-texto analisados, referem-se aos dados biográficos do autor e em apenas um há referência de edição. 
Segundo PFROMM NETO et aliii $^{41}$, ..."para obras do tipo literário, obras técnicas e científicas, é importante saber quem responde pela autoria do texto. Quando se trata de livros didáticos, essa informação é fundamental, pois o autor deve combinar sua competência no assunto com a experiência didática".

A importância de se conhecer os dados sobre os autores de um livro-texto também é mencionada por Brown \& Olmsted apud PFROMM NETO et alii ${ }^{41}$, como referido na introdução do presente trabalho.

Com relação aos ELEMENTOS MECÂNICOS, apenas um dos nove livros-texto analisados possuem a encadernação costurada e colada. Estes fatores influem diretamente na durabilidade e na facilidade de manuseio dos livros-texto.

O papel é de má qualidade em seis dos livros-texto em estudo.

Esta característica se revela importante na legibilidade do texto. Um papel muito fino pode prejudicar sobremaneira a percepção visual das letras, pois a sombra das letras impressas na outra face do papel pode se fazer presente. "Caracteres tipográficos bem escuros e nítidos, em papel opaco, sem brilho, ajudam bastante a visibilidade para a leitura" 4 .

Somente um livro didático possui a capa plastificada, aspecto este que assegura maior durabilidade; este mesmo livro-texto possui a variação das letras em tamanho, cor e estilo, o que torna o livro mais atraente e menos monótono. Dois deles, apresentam apenas a variação de tamanho.

As letras dos vários textos variam de tamanho: cinco livros-texto têm as letras de $2 \mathrm{~mm}$ e quatro deles, as letras de $1,5 \mathrm{~mm}$. O tamanho dos caracteres tipográficos, o tipo de letra, o espaço entre as linhas e entre palavras e linhas e outros, também são importantes para a legibilidade do texto.

A maior parte dos livros-texto estudados possui as linhas distribuídas em duas colunas. Isto permite que os olhos tenham um caminho menor a percorrer e não se cansem pois as linhas são mais curtas e há, portanto maior rendimento da leitura $^{40}$.

Um dos livros-texto em estudo apresenta pouca margem e em outro deles, a impressão é pouco legível devido à transparência.

Com relação às REFERÊNCIAS BIBLIOGRÁFICAS, verificamos que quatro dos nove livros-texto analisados possuem referências bibliográficas, de relativa acessibilidade, de utilidade para o aluno e com relativa atualidade (algumas delas referem-se a período anterior a 1977).

O último quesito que nos resta discutir é referente aos ÍNDICES, APÊNDICES, PREFÁCIO e GLOSSÁRIO.

Apenas uma coleção, que é composta pelos livros-texto 6, 7 e 8, possui índice remissivo no final do livro, o que facilita bastante a procura e localização dos 
assuntos. O restante dos livros-texto analisados possui apenas, como já vimos, índice de capítulos.

Três dos livros-texto estudados possuem apêndice, que num deles não tem relação com o tema abordado no capítulo e em outros é desatualizado. A importância dos apêndices reside no fato de que eles complementam, aprofundam ou mostram uma nova visão sobre um tema determinado.

Em três deles não há prefácio, o que nos leva ao desconhecimento dos objetivos do livro-texto em questão, as explicações necessárias do autor em relação a sua obra e outras informaçōes importantes que queira nos transmitir.

Cinco deles possui glossário, ao final do livro ou mesmo ao final de cada capítulo. Este quesito é importante pois esclarece ao aluno o significado de novas palavras, termos técnicos e científicos, cuja finalidade é aumentar e aprimorar o vocabulário que o estudante tenha incorporado.

Quanto à utilidade prática, podemos dizer que a maior parte deles tem relativa utilidade (principalmente em relação aos apêndices) pois pecam segundo a atualidade.

Os índices de capítulos ou remissivo e o glossário, quando existem, são de grande utilidade pelos motivos acima expostos.

\section{5 - CONCLUSÕES}

O livro didático é o recurso que propicia possíveis mudanças no modo de pensar, sentir e agir do aluno. Possui características específicas, tais como: unidade, coerência, integração e sistematização do conteúdo que veicula. As noçōes "vestidas" com uma roupagem complexa, no livro didático são "traduzidas" para o aluno a que se destina, em informações acessíveis e inteligíveis, e que permitem, portanto, a concretização dos objetivos da aprendizagem.

Nossa formação profissional em Ciências Biológicas e em Enfermagem despertou nosso interesse pelos Programas de Saúde e pelo respectivo livro-texto, pois este constitui um dos instrumentos capazes de levar o homem, pelo conhecimento adquirido, a adotar procedimentos corretos quanto à sua saúde, a de seus familiares e da comunidade em que vive.

A educação da Saúde faz com que os indivíduos participem ativamente das medidas que concorrem para seu bem-estar físico, mental e social.

Extensa foi nossa discussão relativa a formação acadêmica do professor que desenvolve a matéria Programas de Saúde, a série do curso médio em que ela é ministrada, como também qual é a utilização do livro-texto específico.

Julgamos de capital relevância o processo avaliativo do livro-texto e, por isso, resolvemos criar uma ficha analítica para avaliação dos mesmos. Nesta, esta- 
belecemos alguns quesitos a serem considerados, tais como: os dados gerais da publicaçāo, os elementos mecânicos, a organização e apresentação do conteúdo, o conteúdo propriamente dito, exercícios, ilustraçōes, referências bibliográficas, índices, apêndices, prefácio e glossário.

A ficha analítica escolhida é do tipo "checksheet", pois a mesma facilita a rápida avaliação dos quesitos a serem classificados.

Após analisarmos cada livro-texto indicado pelos professores do estudo, preenchermos o conjunto das respectivas fichas analíticas, concluímos que: "muitos erros" são veiculados, principalmente no que se refere às "incorreçōes gramaticais, falta de precisão científica, poucos assuntos tratados e, muitas vezes, pouco aprofundados".

Dos nove livros-texto de Programas de Saúde analisados, cinco foram classificados como regulares e quatro como fracos, o que é para nós, no mínimo alarmante pois, com essa classificaçāo, esses livros-texto não poderão estar possibilitando a concretização do aprendizado como deveriam.

No mundo atual, a mudança social é contínua e rápida e, portanto, rápidas e contínuas devem ser as adaptaçōes culturais, funcionando o livro, como um laboratório de idéias que possibilita o jogo complexo das associaçōes, a análise do universo cultural, o confronto de diferentes pontos de vista. Por meio da palavra escrita, pode-se não somente adquirir cultura, como também modificá-la, recriá-la, ampliá-la.

É mister que, cada vez mais, o professor se conscientize da importância de adotar um bom livro-texto; para isso, é necessário que o faça com o auxílio de um instrumento adequado, que dirija a observação e a reflexão em busca deste objetivo. A partir dessa avaliação e seleção prévias, não só o aluno será beneficiado, como também, em conseqüência disto, os autores e editores começarão a produzir livros-texto de melhor qualidade, que reflitam a realidade para a qual se destina.

Mais uma vez queremos frisar a importância do processo avaliativo do livro-texto, no caso particular, e livros-texto de Programas de Saúde.

Esperamos que o instrumento por nós elaborado, e os estudos futuros que faremos sobre o assunto, ajudem na busca e consecusão do ideal que é o aprimoramento desse material informativo existente - o livro-texto-utilizado para o desenvolvimento dos Programas de Saúde.

MEDEIROS, M.A.Q. de Health programs text books for elementary and high schools: a critical comparative analysis. Rev. Esc. Enf. USP, São Paulo, 23(3):257-293, dez. 1989.

In most of text books for elementary school, health is an appendix in the Science text, and the Health texts for High School consists of a collection of readings, where concepts can be misled and contents are superficial. 
Literature shows articles and research about ether disciplines text-books and a blank space for Health Programs.

The results of this study shows a profile of the teacher Health Programs as well as an analysis of the text books for these programs. The author studies the mecanic elements, contents organization and presentation, contents of the books, exercises, illustration, references and index, apendix, preface and glossary.

UNITERMS: Textbooks, evaluation. Health programas. Health education.

\section{6 - REFERÊNCIAS BIBLIOGRÁFICAS}

\section{1 - REFERÊNCIAS BIBLIOGRÁFICAS GERAIS}

I ALBUQUERQUE, F.F.L. Que sabemos sobre o livro didático. Rev. bras. Est. pedag., Rio de Janeiro, 61(138): 218-22, abr./jun., 1976.

2 ALVARES, B. et alii. Análise das informações veiculadas por material didático para o ensino de biologia no 2 grau. Ci. e Cult., São Paulo, 30(supl.): 107, jul. 1978.

3 BALAU, V.L. Texto didático: reflexões sobre análise do conteúdo e análise do discurso. Sāo Paulo, 1981. 70 p. (Dissertação de mestrado - Pontifícia Universidade Católica de São Paulo).

4 BARBANTI, M.L.S.H. Antigos manuais de ensino. Ci. e Cult., São Paulo, 34(supl.): 150, jul. 1982.

5 BASTOS, N.C.B. Educação para a saúde na escola. Rev. Fund. SESP, Rio de Janeiro, 24(2): $35-49,1979$.

6 BITTENCOURT, S.T. Livro didático de português: diagnóstico de uma realidade. Curitiba, 1982. 120 p. (Dissertação de mestrado - Universidade Federal do Paraná).

7 BORGES, G.L.A. Utilização do método científico em livros didáticos de ciências 1" grau. Campinas, 1982. 243 p. (Dissertação de mestrado - Universidade Estadual de Campinas).

8 BRASIL. Leis, decretos, etc. Lei no 5692/71 de 11 de ago. de 1971. Documenta, Brasília, (129): 400-416, ago. 1971. Fixa as diretrizes e bases para o ensino de $1^{\circ}$ e $2^{\circ}$ graus e dá outras providências.

9 BRASIL. Leis, decretos, etc. Lei no $5988 / 73$ de 14 de dez. de 1983. Rev. bras. Bibliotecon. e Doc., São Paulo, 13(1/2): 95-106, jan./jun. 1980.

10 - Parecer n 603/68 de 4 de out. de 1968. Documenta, Brasília, (92): 9-12, out. 1968. Fixa o período para substituição de livros didáticos.

11 . Parecer n 809/73 de 7 de jun. de 1973. Documenta, Brasília, (151): 133-4, jun. 1973. Dispōe sobre licenciados em enfermagem participarem em programas de magistério.

12 Parecer n² 2264/74 de 6 de ago. de 1974. Documenta, Brasilia, 13(165): 63-83, ago. 1974. Fixa o ensino de programas de saúde no $1^{\circ}$ e $2^{\circ}$ Graus.

13 - Parecer n 47/86 de 30 de jan. de 1986. Documenta, Brasília, (301): 35-6, jan. 1986. Dispōe sobre questões levantadas relativas a disciplina "programas de saúde".

14 …. Portaria n” 518 - B5B/73 de 10 de set. de 1973. Diário Oficial, Brasília, 17 set. 1973. p. 9307 . Dispōe sobre o regimento do Programa do livro Didático de Educação Fundamental - PLIDEF

15 - Portaria n" 35/85 de 27 de nov. de 1985. Documenta, Brasília, (301): 215-8, jan. 1986. Estabelece instruçōes para expedição do registro profissional dos professores especialistas em educação. (Anexo 7).

16 - Resolução n״ 04/72 de 25 de fev. de 1972. Documenta, Brasília, (140). 566-8, jul. 1972. Dispôe sobre o currículo mínimo dos cursos de enfermagem e obstetrícia.

17 COSTA, 1.S. Educação em saúde escolar: análise de uma experiência. Rev. Bras. Enf., Rio de Janeiro, 27(1): 98-111, jan./mar. 1974.

18 COSTA, J. Assistência de enfermagem ao escolar. Rev. Paul. Enf., São Paulo, 3(5): 159-60, out./dez. 1983.

19 CREIDY, O. O ensino de línguas vivas. Veritas, Porto Alegre, 24(94): 175-9, jun. 1979.

Rev. Esc. Enf. USP, Sāo Paulo 23(3):257-293, dez. 1989 
20 CYSNEIROS, P.G. Uma análise crítico-comparativa de livros-texto de psicologia educacional.

Ci. e Cult., Sảo Paulo, 35(supl.): 142, jul. 1983.

21 FRANCO, M.L.P.B. O livro didático de história do Brasil: algumas questōes. Cad. Pesq., Sāo Paulo, (41): 22-7, maio 1982.

22 JORGE, A.E.S. Educação para a saúde: um estudo de caso em curso supletivo. Rio de Janeiro, 1983. 180 p. (Dissertação de mestrado - Instituto de Estudos Avançados em Educação da Fundaçāo Getúlio Vargas).

23 JUNQUEIRA, L.A.P. Mudanças na prática de saúde da família: a mediaçāo do escolar. Ci. e Cult., São Paulo, 31(supl.): 122, jul. 1979.

24 KRASilchicK, M. Prática de ensino de biologia. Sāo Paulo, Habra, 1983. 203 p.

25 LIMA, R.N.S. A pedagogia presente na elaboração do livro didático de matemática. Rev. bras. Est. pedag., Brasília, 63(144): 10-25, maio/ago. 1979.

26 MARIZ, C.L. Ideologia no ensino de ciências e saúde no $1^{\circ}$ grau. Ci. e Cult., Sāo Paulo, 35(supl.): 138, jul. 1983.

27 -. Tex to didático e criança carente. Ci. e Cult., São Paulo, 35(supl.): 137, jul. 1983.

28 MATOS, F.G. \& CARVALHO, N. Como avaliar um livro didático-língua portuguesa. São Paulo, Pioneira, 1984. $78 \mathrm{p}$.

29 MEDEIROS, E.B. As provas objetivas: técnicas de construção. 2 ed. Rio de Janeiro, Fundação Getúlio Vargas, 1972. $188 \mathrm{p}$.

30 MELO, J.A. O ensino de saúde no $1^{\circ}$ grau. Ci. e Cult., São Paulo, 28(supl.): 703, jul. 1976.

31 MENEGALE, H. Sobre o livro didático. Educação, Brasília, 1(2): 85-7, jul./set. 1971.

32 MOlina, O. O livro didático. Comun. e Artes, São Paulo, (11): 125-38, 1982.

33 MOYSÉS, S.M.A. O estudo sobre a adequação de livros didáticos de comunicaçāo e expressão no 1" grau em Natal. Ci. e Cult., Sảo Paulo, 33(supl.): 135, jul. 1981.

34 MUNIZ, P.P. O livro didático de física. Curriculum, Rio de Janeiro, 4(7): 88-92, 1965.

35 NÉRICI, I.G. Material didático. In:_—__ Introdução à didática geral: dinâmica da escola. 3 ed. São Paulo, Fundo de Cultura, 1965. cap. 10, p. 294-350.

36 OLIVEIRA, I.E. Recursos audiovisuais: demonstraçāo didática-pesquisa do ensino. Curriculum, Rio de Janeiro, 7(13): 17-43, 1968.

37 OLIVEIRA, J.B.A. Os livros descartáveis: exigência pedagógica ou apenas um bom negócio? Cad. Pesq., São Paulo, (44): 90-94, fev. 1983.

38 - Subsídios para uma política do livro-didático. Rio de Janciro, Instituto Nacional de Estudos Pedagógicos, 1983. 40 p.

39 Oliveira, J.B.A. et alii. A polftica do livro didático. Sāo Paulo, Summus, 1984.139 p.

40 PFROMM NETO, S. Alguns aspectos da psicologia do livro e da leitura. Comun. e Artes, São Paulo, (11): 151- 72, 1982.

41 PFROMM NETO, S. et alii. O livro na educaçāo. Rio de Janeıro, Primor/INL, 1974.256 p.

42 PHILLIPS, C.G. \& HARMAN, E. Criteria for selecting textbooks. Nurse Educ., Philadelphia, 11(2): 31-34, Mar./Apr. 1986.

43 O POBRE livro brasileiro. Ci. e Cult., São Paulo, 29(1): 103-5, jan. 1977.

44 PONDÉ, G. et alii. O livro didático na árca de comunicação e expressão: algumas idéias. Ci. e Cult., Sāo Paulo, 38(5): 829-35, maio 1986.

45 PRETTO, N.L. Os livros de ciências da primeira à quarta série do 1"' grau. Salvador, 1983.115 p. (Dissertaçâo de mestrado -- Universidade Federal da Bahia).

46 RODRIGiUes, M.A. Enfermeira na saúde escolar. Rev. Paul. Enf., Sāo Paulo, 3(2): 50-3, mar./ abr. 1983.

47 SANGIORGI, O. Nascimento, paixāo e vivência de novas tecnologias no livro didático de matemática. Com. e Artes, São Paulo, (11): 189-98, 1982.

48 SANTOS, C.C. et alii. Algumas características dos livros didáticos de química do 2\% grau. Ci. e Cult., São Paulo. 31(supl.): 115, jul. 1979.

49 SĀO PAULO (Estado) Secretaria da Educação. Coordenadoria de Estudos e Normas Pedagógicas. Proposta curricular para programas de saúde: 2 grau. São Paulo, 1981. 17 p. 

Subsidios para a implantação do guia curricular de programas de saúde: 19 grau. São Paulo, 1981.

51 - Subsídios para a implantação do guia curricular de programas de saúde: $1^{\circ}$ grau. $\quad 2$ ed., São Paulo, 1982 . 189 p.

52 SÃo PAULO. Leis, decretos, etc. Lei no $1.925 / 78$ de 29 de dezembro de 1978. São Paulo. Leis e Decretos, São Paulo, 88: 208 mar./dez. 1978. Dispóe sobre o disciplinamento na substituição de livros didáticos nas escolas de $1^{\circ}$ e $2^{\circ}$ graus.

53 - Resolução SE no 113/76 de 31 de março de 1976. Diário Oficial, São Paulo, 31 de março de 1976. p. 2025-2026. Dispốe sobre a adoçāo de livros didáticos.

54 SCHEER, J.K. et alii. Shopping for the best text. Health Educ., Washington, 8(6): 26-27, nov./dec. 1977.

55 SERBINO, R.V. Condiçōes da educação para a saúde no ensino de $1 \%$ grau. Botucatu, 1973. 220 p. (Tese de doutorado - Faculdade de Ciências Médicas e Biológics de Botucatu).

56 _. Educação para a saúde na escola. Ci. e Cult., São Paulo, 27(supl.): 705, jul. 1975.

57 SILVA, T.R.N. O livro didático: reflexōes sobre os critérios de utilizaçāo e seleçāo. Cad. Pesq., São Paulo, (44): 98-101, fev. 1983.

58 SILVEIRA, R.M.G. História: preocupação com o livro didático. Ci. e Cult., São Paulo, 29(5): 623624 , maio 1977.

\section{2 - REFERÊNCIAS BIBLIOGRÁFICAS ESPECÍFICAS: LIVROS-TEXTO ANALISADOS}

1 ENS, W. \& LAGO, S.R. Ciências - a terra: o meio ambiente e os recursos naturais-saúde. São Paulo, Instituto Brasileiro de Ediçóes Pedagógicas - IBEP, s.d. 166 p.

2 FERNANDES, N.P. \& CARVALHO, O.B. Estudando a energia: programas de saude e ecologia: 8 " série. Săo Paulo, Instituto Brasileiro de Edições Pedagógicas - IBEP, s.d. 142 p.

3 - Estudando o ambiente: programas de saúde e ecologia: 5' série. São Paulo, Instituto Brasileiro de Ediçōes Pedagógicas - IBEP, s.d. 120 p.

4 LOPES, P.C. $O$ ambiente: ciências e saúde: 5" série, $1^{0}$ grau. 8 ed., São Paulo, Saraiva, 1986. $168 \mathrm{p}$.

5 MARCONDES, A.C. Programas de saúde. Sāo Paulo, Atual, 1983. 234 p.

6 VILELA, C.R. et alii. Ciências e programas de saúde: 6 série, 10 grau. São Paulo, Atual, 1977. $159 \mathrm{p}$.

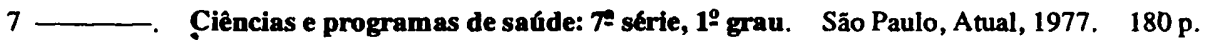

8 - Ciências e programas de saúde: 8 série, 1 grau. São Paulo, Atual, 1978. 210 p.

9 ZEINUM, R. Ciências: corpo humano: satude e ecologia. São Paulo, Instituto Brasileiro de Ediçōes Pedagógicas - IBEP, s.d. v.2. 
FICHA ANALITICA PARA AVALIAÇĀO DE LIVROS-TEXTO*

Cada quesito será valorizado de 0 a 5 pontos, obedecendo os seguintes criterios: $0=$ nulo (-)

$$
\begin{aligned}
& 1=\text { pessimo }(*) \\
& 2=\operatorname{fraco}(* *) \\
& 3=\operatorname{regular}(* * *) \\
& 4=\operatorname{bom}\left({ }^{* * * *}\right) \\
& 5=6 \operatorname{timo}(* * * *)
\end{aligned}
$$

O ítem APRESENTAÇĀo DO CONTEÚDO terá peso 3; os ítens ORGANIZAÇĀo DO CONTEÚDO, CONTEÚDO PROPRIAMENTE DITO E EXERCICIOS, QUESTIONÁRIOS E EXEMPLOS terão peso 2; os demais ítens terão peso 1, perfazendo um total de 330 pontos.

\section{DADOS GERAIS SOBRE A PUBLICAÇÃO:}

Título:

\section{Autor(es)}

Editor:-

Edição (reimpressāo):

Ano:-

Número de páginas:-

Número de capítulos:

Assunto:

Série a que se destina:

\section{ELEMENTOS MECÂNICOS:}

- Aspecto material: - encadernação-

- Impressão: $\begin{aligned} \text { - letra- } \\ \text { - linhas } \\ \text { - impressão propriamente dita_ }\end{aligned}$
- TOTAL:

$$
\text { - papel }
$$

ORGANIZAÇĀO DO CONTEÚDO:

- Plano geral

- Seqüencia lógica

- Sumário, resumo, quadro sinótico

- TOTAL: $\mathbf{X}$

4. APRESENTAÇĀO DO CONTEÚDO:

- Relevância

- Estilo

- Correção gramatical

- Vocabulario

- Ausência de estereotipos

- Atualidade

- Precisão científica

- Essencial ressaltado

- TOTAL $\mathrm{X}$

\section{CONTEÚDO PROPRIAMENTE DITO:}

- Adequação ao nível do aluno

- Aplicaçóes práticas

- Relaçăo com outras disciplinas

- Motivaçāo para leituras complementares, observaçōes

- Favorece o espírito crítico e a capacidade de resolver problemas

- TOTAL_—X

* adaptado de CUNHA, CREIDY, KRASILCHICK, MATOS, ZA. 
6. EXERCICIIOS, QUESTIONÁRIOS E EXEMPLOS:

- Relação direta com o conteúdo

- Quantidado

- Dificuldade graduada

- Estímulo à criatividade

- TOTAL —X

7. ILUSTRAÇŌES (ESTAMPAS, MAPAS, ESQUEMAS E GRÁFICOS):

- Quantidado

- Objetividade

- Valor

- Atratividado

- TOTAL _ X X X X X X

8. REFERÊNCIAS BIBLIOGRÁFICAS:

- Acessibilidade

- Utilidade para o aluno

- Utilidade para o professor

- Atualidade

- TOTAL

9. INDICES, APÊNDICES, PREFÁCIO, GLOSSÁRIO:

- Conteúdo

- Utilidade prática

- Disposição/apresentação

- Atualidade

- TOTAL

TOTAIS: ELEMENTOS MECÂNICOS

ORGANIZAÇĀO DO CONTEÚDO

APRESENTẢÇĀO DO CONTEÚDO

CONTEÚDO PROPRIAMENTE DITO

EXERCICIOS, QUESTIONÁRIOS E EXEMPLOS

ILUSTRAÇŌESS

REFERÊNCIAS BIBLIOGRÁFICAS

INDICES, APÊNDICES, PREFÁCIO, GLOSSÁRIO

TOTAL GERAL

CLASSIFICAÇÃO GERAL DO LIVRO-TEXTO:

de 0 a 60 pontos $=$ nulo

de 61 a 120 pontos $=$ péssimo

de 121 a 180 pontos $=$ fraco

de 181 a 240 pontos $=$ regular

de 241 a 300 pontos $=$ bom

de 301 a 330 pontos $=6$ timo

INFORMAÇŌES COMPLEMENTARES: 


\section{ANEXO 2}

Prezado(a) Professor(a),

O presente questionário é destinado a você que desenvolve os Programas de Saúde em escola pública estadual de $1^{\circ}$ e/ou $2^{\circ}$ graus e tem por finalidade analisar crítica e comparativamente os livros-texto que abordam os Programas de Saúde.

$O$ (a) diretor(a) de sua escola estará encarregado(a) de distribuir os questionários e recebê-los preenchidos no prazo de 20 (vinte) dias após a entrega.

Responda às perguntas que se seguem com sinceridade e agradecemos desde já sua colaboração.

Sugestōes são bem vindas para enriquecer nossa pesquisa que pretende melhorar os textos relativos aos Programas de Saúde.

Maria Angela Quilici de Medeiros Auxiliar de Ensino do Departamento de Orientação Profissional da Escola de Enfermagem da Universidade de São Paulo. 


\section{QUESTIONÁRIO PARA COLETA DE DADOS}

\begin{tabular}{|c|c|c|c|}
\hline \multirow[t]{2}{*}{ NÚMERO } & \multirow[t]{2}{*}{ QUESTŌES } & \multicolumn{2}{|c|}{ TABULAÇÃO } \\
\hline & & COL. & TAB. \\
\hline 1. & Número do questionário & 1 a 3 & \\
\hline 2. & $\begin{array}{l}\text { Qual é(foi) o Curso de Graduação por } \\
\text { você freqüentado? } \\
\begin{array}{ll}\text { 1. Ciências } \\
\text { 2. Ciências Biológicas }\end{array} \\
\begin{array}{ll}\text { 3. Outro. Qual? } & \text { ( ) } \\
& \text { ( ) }\end{array}\end{array}$ & 4 & \\
\hline 3. & $\begin{array}{l}\text { Em que período você terminará } \\
\text { (terminou) a licenciatura? } \\
\text { 1. } 1986-1982 \\
\text { 2. } 1981-1977 \\
\text { 3. Antes de } 1977\end{array}$ & 5 & \\
\hline 4. & $\begin{array}{l}\text { Quais são as disciplinas que você } \\
\text { ministra neste estabelecimento escolar, } \\
\text { além dos Programas de Saúde? } \\
\text { 1. Ciências } \\
\text { 2. Ciências Biológicas } \\
\text { 3. Outras. Quais? }\end{array}$ & 6 & \\
\hline 5. & $\begin{array}{l}\text { Os Programas de Saúde constituem uma } \\
\text { disciplina independente? } \\
\text { 1. Sim } \\
\text { 2. Não }\end{array}$ & 7 & \\
\hline 6. & $\begin{array}{l}\text { Em caso de resposta negativa à questão } \\
\text { anterior, qual disciplina desenvolve os } \\
\text { Programas de Saúde? } \\
\text { 1. Ciências } \\
\text { 2. Ciências Biológicas } \\
\text { 3. Outra. Qual? ( ) }\end{array}$ & 8 & \\
\hline
\end{tabular}




\begin{tabular}{|c|c|c|c|}
\hline \multirow[t]{2}{*}{ NÚMERO } & \multirow[t]{2}{*}{ QUESTÖES } & \multicolumn{2}{|c|}{ TABULAÇÃO } \\
\hline & & COL. & TAB. \\
\hline 7. & \begin{tabular}{l}
\multicolumn{3}{r}{ Em que séries você ministra os } \\
Programas de Saúde? \\
1. $5^{\text {a }}$ série do $1^{\circ}$ grau \\
2. $6^{\text {a }}$ série do $1^{\circ}$ grau \\
3. $7^{\text {a }}$ série do $1^{\circ}$ grau \\
4. $8^{\text {a }}$ série do $1^{\circ}$ grau \\
5. $1^{\text {a }}$ série do $2^{\circ}$ grau \\
6. $2^{\text {a }}$ série do $2^{\circ}$ grau \\
7. $3^{\text {a }}$ série do $2^{\circ}$ grau
\end{tabular} & 9 & \\
\hline 8. & $\begin{array}{l}\text { Qual é a carga horária semanal destinada } \\
\text { aos Programas de Saúde nas séries } \\
\text { do } 1^{\circ} \text { grau? } \\
\text { 1. } 1 \text { hora/aula } \\
\text { 2. } 2 \text { horas/aula } \\
\text { 3. } 3 \text { horas/aula } \\
\text { 4. Não há carga horária estabelecida () }\end{array}$ & 10 & \\
\hline 9. & $\begin{array}{l}\text { Qual é a carga horária semanal destinada } \\
\text { aos Programas de Saúde nas séries } \\
\qquad \begin{array}{l}\text { do } 20 \text { grau? } \\
\text { 1. } 1 \text { hora/aula } \\
\text { 2. } 2 \text { horas/aula } \\
\text { 3. } 3 \text { horas/aula } \\
\text { 4. Não há carga horária estabelecida () }\end{array}\end{array}$ & 11 & \\
\hline 10. & $\begin{array}{l}\text { Você adota livro-texto para desenvolver } \\
\text { os Programas de Saúde? } \\
\begin{array}{ll}\text { 1. Sim } & \text { ( ) } \\
\text { 2. Não } & \text { () }\end{array}\end{array}$ & 12 & \\
\hline 11. & $\begin{array}{l}\text { Em caso de resposta afirmativa à } \\
\text { questão anterior, estes livros-texto } \\
\text { contém exclusivamente os conteúdos } \\
\text { relativos aos Programas de Saúde? } \\
\text { 1. Sim } \\
\text { 2. Não }\end{array}$ & 13 & \\
\hline
\end{tabular}




\begin{tabular}{|c|c|c|c|}
\hline \multirow[t]{2}{*}{ NÚMERO } & \multirow[t]{2}{*}{ QUESTÕES } & \multicolumn{2}{|c|}{ TABULAÇÃO } \\
\hline & & COL. & TAB. \\
\hline 12. & $\begin{array}{l}\text { Você utiliza algum instrumento para } \\
\text { avaliar um livro-texto de Programas de } \\
\text { Saúde antes de adotá-lo? } \\
\text { 1. Sim } \\
\text { 2. Não }\end{array}$ & 14 & \\
\hline 14. & 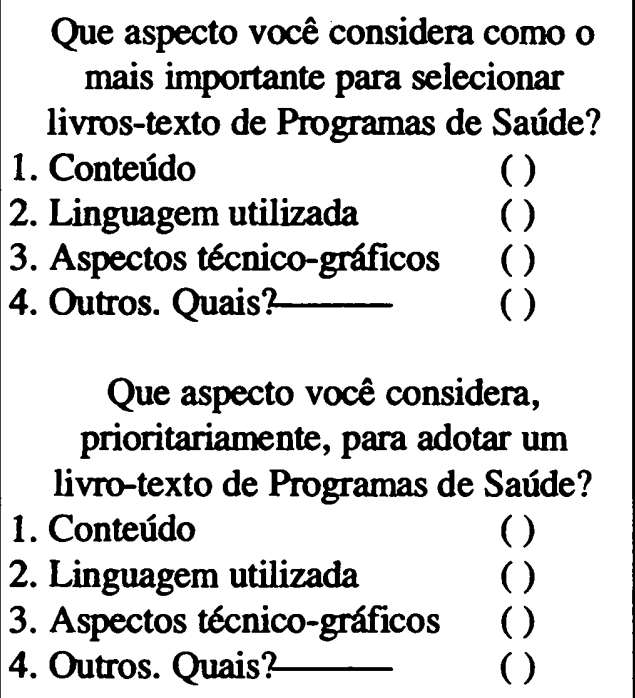 & 15 & \\
\hline 15. & $\begin{array}{l}\text { Este aspecto é reservado para você } \\
\text { referir TODOS os livros-texto que você } \\
\text { utiliza para desenvolver os Programas } \\
\text { de Saúde. Se possível, dê o nome } \\
\text { completo da obra, autor e para que } \\
\text { série é destinado. }\end{array}$ & 17 & \\
\hline 16. & Informaçōes complementares: & $18-19$ & \\
\hline 17. & Sugestōes: & $20-21$ & \\
\hline
\end{tabular}

Muito agradecida mais uma vez 